\title{
The principle of maslahah and its application in Islamic banking operations in Malaysia
}

\author{
Muhammad Shahrul Ifwat Ishak \\ Faculty of Economics and Management Sciences, \\ Universiti Sultan Zainal Abidin - Kampus Gong Badak, Kuala Terengganu, \\ Terengganu, Malaysia
}

\section{Islamic \\ banking \\ operations in \\ Malaysia}

\begin{abstract}
Purpose - This paper aims to investigate the extent to which maslahah (public interest) is taken into consideration in Islamic banking operations in Malaysia, particularly in bay al-'inah (sale and buyback), ta' wid (compensation) and $i b r \bar{a}$ ' (rebate).

Design/methodology/approach - This study applies deductive and inductive methods to analyze the application of maslahah in Islamic financial transactions. Three issues in Malaysia are selected as a case study, allowing bay' al-'inah, standardizing the rate of ta' wid and stipulating the $i b r \bar{a}$ ' clause in financial agreements. As this study is qualitative in nature, all data are analyzed based on the content analysis method.

Findings - Both the maslahah of Islamic banks and their customers were found to be considered by the Central Bank of Malaysia in the implementation of contracts and principles of Islamic banking. The first maslahah represents the viability of Islamic banks, while the second maslahah promotes fairness and transparency between Islamic banks and their customers.

Research limitations/implications - This study only focuses on the contracts and principles of Islamic banking operations in Malaysia with regard to three selected issues.

Practical implications - This paper clarifies the practical application of mașlahah in the Islamic banking industry, particularly with regard to implementing its contracts and principles.

Originality/value - This paper analyzes the argument of maslahah on the issues of bay' al-'inah, ta' wid and $i b r \bar{a}$ ' in Malaysia, which are considered among scholars to be debatable issues. While many discussions focus on the legal aspect of Sharī'ah on those issues, this study emphasizes how the application of maslahah aims to solve the current problems and harmonize between Sharī'ah and reality.
\end{abstract}

Keywords Islamic banking, Bay' al'‘ñnh, Ibrā', Mașlahah, Ta'wid

Paper type Research paper

\section{Introduction}

Malaysia has one of the largest Islamic banking industries worldwide. With 17 Islamic financial institutions (IFIs) (local and foreign) operating competitively, Islamic banking comprises almost 22 per cent of the total national banking sector of the country. Furthermore, it is argued that Malaysia was the first to establish the Islamic interbank money market, a fully-fledged Islamic stockbroking company, corporate șukūk (Islamic

(C) Muhammad Shahrul Ifwat Ishak. Published in ISRA International Journal of Islamic Finance. Published by Emerald Publishing Limited. This article is published under the Creative Commons Attribution (CC BY 4.0) licence. Anyone may reproduce, distribute, translate and create derivative works of this article (for both commercial and non-commercial purposes), subject to full attribution to the original publication and authors. The full terms of this licence may be seen at http:// creativecommons.org/licences/by/4.0/legalcode

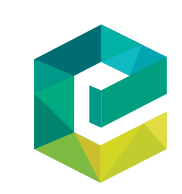

Received 30 January 2018

Revised 14 February 2018 7 June 2018

13 February 2019

Accepted 21 February 2019

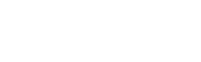

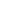


bond) and Islamic unit trusts (Shaharuddin, 2012). Malaysia has also contributed the largest part of research in Islamic finance (Ernst and Young, 2016).

In terms of regulations, Malaysia has been identified as the most advanced country in promoting Islamic finance via a comprehensive legal framework (Askari et al., 2009). The recent Islamic Financial Services Act 2013 (IFSA) is a clear example of how seriously the government is promoting Sharīah compliance in Islamic financial instruments. In other words, IFSA provides a comprehensive legal framework that is fully consistent with Shar' ah (Islamic law) in all aspects of regulation and supervision, from licensing to the winding-up of an institution (Yusof, 2017). For the purpose of validating Islamic banking, the Shariah Advisory Council (SAC) of Bank Negara Malaysia (BNM), the central bank, was set up in 1997 (ISRA, 2011).

Representing the highest Shari ${ }^{-}$ah authority in Islamic finance, the SAC has issued many resolutions, some of which are mandatory for IFIs in Malaysia. These include parameters for Sharīah contracts and Islamic financial practices. It is clear that in every resolution, the SAC produces relevant justifications from Sharī'ah sources, as well as the views of scholars, to validate its decisions. Nevertheless, some of them are not in line with other international Islamic bodies, and also are not being practiced by Islamic banks in other Muslim nations, particularly Middle Eastern countries. Such resolutions, for instance, allow bay' al-'inah (sale and buyback), standardization of the rate of ta' wid (compensation) and stipulation of the $i b r \bar{a}$ ' (rebate) clause in financial agreements. As the issues of Islamic banking are quite complicated and some of them cannot be directly taken from classical works of jurisprudence, maslahah has become one of the main approaches in dealing with those modern issues. This concept, which reflects the idea of achieving public interest and averting harm, has played a significant role both in establishing rules and in developing products.

While those practices are justified on the basis of maslahah (public interest), they need greater clarification in terms of which maslahah is being considered, particularly by regulators. This paper thus aims to investigate the extent to which maslahah is taken into consideration in Islamic banking operations in Malaysia, particularly in respect of the three selected issues, bay' al' 'inah, ta'wid and $i b r \bar{a}^{\prime}$. It uses content analysis to examine the application of maslahah in Islamic financial transactions.

The rest of the paper is organized as follows: the next section explains the principle of maslahah and its significant role in addressing modern issues, including Islamic finance. It then proceeds to examine its application by analyzing three Islamic banking issues in Malaysia, allowing bay al'inah, standardizing the ta'wid (compensation) rate and stipulating $i b r \bar{a}$ in financial agreements. It then concludes with a summary of the discussion.

\section{The principle of maslahah in Islamic finance}

Technically speaking, maslahah can be defined as an attribute of an act that realizes benefits - an act which always or usually benefits the public or individuals (Ibn 'Āshūr, 2001). This term is embodied within the maqūssid al-Sharīah (objectives of Islamic law), which is the meaning and wisdom that are emphasized by God in His rules (Al-Yūbī, 1998). In this regard, instead of being restricted to the literal textual meaning, the verses pertaining to a rule in Islamic sources, namely, the Qur' ān and the Sunnah, must be engaged implicitly and understood in the right context to determine particularly what mașlahah is behind the rule (Al-Kaylānī, 2008).

Many texts of the Qur'ann and the Sunnah point to the element of maslahah as the purpose of Islam. One example is related to the case of mercy: "And we have not sent you, $(\mathrm{O}$ 
Muhammad), except as a mercy for all creatures” (Qur'ān, 21:107). Another example is about avoiding difficulties: "Allah does not wish to place you in difficulty but, rather, to purify you and complete His favor to you" (Qur'ān, 5:6). At the same time, several rules hold an additional maslahah, such as the rule of qișās (proportional retribution): "Fair retribution saves life for you" (Qur'ān, 2:179).

Furthermore, looking at the practices of the rightly guided caliphs, the first four successors of Prophet Muhammad (peace be upon him), it is noted that most of their policies were based on maslahah. These included compiling the Qur'ān as a single book, banning interfaith marriage, declaring divorce which is uttered three times at once to count as three times, selling any lost camel and imposing a fine on craftsmen for the loss or damage to customers' property (Al-Khādimī, 2010).

While maslahah had been practiced since the time of the Prophet (peace be upon him), his companions and the early generations, its theory was only systematically written about between the fifteenth and eighteenth centuries C.E. (Auda, 2007). Therefore, it is claimed as the last theory in the development of Islamic jurisprudence (Laluddin, 2015). A group of scholars including al-Juwaynī, al-Ghazālī and 'Izz ibn 'Abd al-Salām were among the pioneers in introducing mașlahah, its dimensions and its priority (Al-Yūbī, 1998). The next group, comprising Ibn Qayyīm, al-Qarāfī and al-Shāțibī, developed mașlahah as an independent topic in $u s \underline{u} \bar{l}$ al-fiqh (the principles of Islamic jurisprudence). Moreover, the discussion has been expanded to cover the parameters of maslahah, dealing with possible clashes between various mașälih (pl. of mașlahah), the issue of hiy $\bar{a} l$ (legal stratagems) and the application of maslahah in Islamic jurisprudence (Al-Raisūnī, 1995).

The role of maslahah has become more crucial in modern times, particularly in applying Islam in the reality of modern life. With the drastic changes in society, technology, politics and economics, maslahah plays a significant role in reforming Islamic practices (AlKhādimī, 2010). This includes dealing with new issues such as banking and finance, politics, medical issues and problems associated with Muslim minorities (Al-Qarad̄āwī, 2006). Not surprisingly, today, many resolutions from Islamic bodies, fatwas and Islamic rules are based on maslahah.

To conclude, the concept of maslahah represents an approach in Islamic jurisprudence that aims to harmonize between revelation and real situations. A balance must be struck between indiscriminate amendments to the practices of Islam in the name of "human wellbeing" and a mechanically literal application of Islamic texts without any consideration of circumstances and consequences (Malik, 2011). In this regard, it should be understood that rules in Islam should not merely be determined from the theoretical aspect, through Islamic sources or classical works of scholars, but their outcomes also need to be considered as to how far they realize maslahah in concrete situations (Al-Raisūnī, 1995).

The classical issue of price fixing provides a clear example. At first, this action was not preferred by Prophet Muhammad (peace be upon him) because he said:

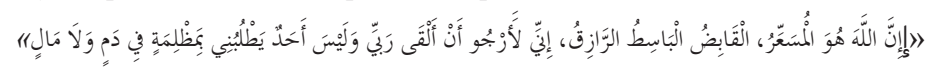

Indeed, Allah is the determiner of prices, the Constrictor, the Expander, the Provider. I wish to meet my Lord without anybody demanding restitution of me regarding blood or property (Ibn Mājah, 2000).

Analyzing the statement of the Prophet (peace be upon him) gives a clear picture regarding why this action was prohibited during his time. As the price rise was because of limited resources, it would have been unfair to force sellers to reduce the price (Hassan, 2006). Thus, mastahah for the sellers at that time had a greater right of consideration than maslahah of the society. Nevertheless, a few decades later, during the era of the Tābi inn (the 
generation after the Companions), some scholars such as al-Layth ibn Sa 'd, Rabī'ah and Yahyā ibn Ma īn argued to allow this action because of maslahah for the society (Al-Dūrī, 2011). As the price rise occurred because of market manipulation at that time, it was more important to consider the maslahah of the society (Ahmad Bashar, 1997).

\section{A case study of Malaysia}

Based on the concept of mașlahah, a few cases of Islamic banking operations in Malaysia are analyzed hereunder.

\section{Allowing bay' al'-'inah}

Bay' al-'inah is practiced by selling an item for a deferred payment, then buying it back at a lower price in cash (ISRA, 2009). This practice is also known as bay' al-äjāl among Mālikis and Shafi 'is (Mansour, 2007). In modern Islamic banking operations, bay' al-'inah is used both as a direct financing method between Islamic banks and their customers, or as a combination with other contracts such as bay' bithaman äjil (deferred payment sale), known as BBA, and organized tawarruq (monetization) (Mohammad et al., 2013).

Bay' al-'inah has received criticisms from both classical and contemporary Muslim scholars regarding its Sharī'ah status. While the majority of scholars rejected bay' al-'inah, claiming it to be a trick to circumvent to the prohibition of $r i b \bar{a}$ (interest), some early jurists such as Ibn 'Umar, Abū Yūsuf, the Shafi'îs and Zāhirīs allowed this contract (Lahsasna, 2014). al-Shāfi 'i (2001), for example, rejected the argument of a trick to legalize riba $\bar{a}$, as he considered bay' al-'inah as two separate contracts. In terms of modern discussions, this contract is not favored by many Islamic bodies. The International Islamic Fiqh Academy (IIFA), for example, in its resolution on muwa a $a d a h$ (bilateral promise) in a financial contract, mentioned that an agreement from the contracting parties in order to circumvent the prohibition of rib $\bar{a}$ - for example, bay al' ' $\bar{m}$ ah - is not allowed in Sharī'ah (IIFA, 2006). Another organization that takes a similar view is the Accounting and Auditing Organization for IFIs (AAOIFI). In its Sharī'ah standard on tawarruq, one of the conditions of its practice is that it must avoid bay' al-' $m a h$, which is strictly prohibited (AAOIFI, 2010).

Nevertheless, the SAC of BNM has developed a different approach by allowing bay al'inah for Islamic banks in Malaysia. In its first meeting, dated 8 July 1997, the SAC resolved that the issuance of Negotiable Islamic Debt Certificates based on the bay' al-' inah concept is permissible. This decision was justified with the general verse permitting sale in the Qur'ān, as well as the view of early scholars who allowed this contract, including Abū Yūsuf and alShafi ' 1 (BNM, 2010). Subsequently, special resolutions on the permissibility of bay al' 'inah as an instrument in the Islamic interbank money market and for offering Islamic credit cards were issued by the SAC (BNM, 2010).

Even though the central bank did not clearly mention the justification of maslahah, some researchers claimed that bay' al-'inah is allowed in Malaysia since this contract promoted Islamic banking, particularly during the first period of this industry (Tita and Saim, 2012). Moreover, as this contract is used in the structuring of Islamic credit cards, which today are crucial for daily business dealings and commercial transactions, it is considered as maslahah for the people (Shaharuddin, 2012). As for the maslahah of Islamic banks, as there are many restrictions in terms of alternatives, this contract is important to provide liquidity for Islamic banks (Md. Hashim et al., 2015). In fact, liquidity represents a darūrah (necessity) for a banking institution to compensate for expected and unexpected balance sheet fluctuations, and to provide funds for growth (Iqbal and Mirakhor, 2007). In other words, it represents a bank's ability to accommodate the redemption of deposits and other liabilities, 
as well as to cover the demand for loan and investment funding (Van Greuning and Iqbal, 2008).

Nevertheless, considering the controversy surrounding bay' al-'inah, the central bank has discouraged Islamic banks from using this instrument in their financing products (BNM, 2007). Moreover, the central bank has attempted to strengthen the application of bay al-'inah and enhance its operational processes and documentation to comply with the theoretical features of bay' al-' 'mah that are mentioned by scholars who favor it. This can be seen when, in 2009, the central bank tightened the parameters of bay' al-' $i n a h$, stating that it must consist of two clear and separate contracts without stipulated condition in the sale contract to repurchase the asset. In addition, both contracts should be concluded at different times (BNM, 2010). This approach, it is argued, has successfully encouraged Islamic banks to replace this contract in their products (Amer Hamzah and Vizcaino, 2014). Another approach to minimize the influence of bay 'al-'inah has been to introduce Bursa Suq al-Sila' (BSAS). This special exchange was introduced by Bursa Malaysia for practicing tawarruq because it can avoid the element of bay' al-' inah as the sale to the commodity supplier is carried out on a random basis (Dusuki, 2010).

Through this issue, it is learnt that the application of maslahah must be carried out realistically in order to successfully achieve it without causing any adverse result. While it is undeniable that bay' al-' inah is a controversial contract in terms of its status, it also provides maslahah. Therefore, it is important to engage with this issue gradually, considering its impact on the Islamic banking industry. Moreover, it is important to note that the technical issues in Islamic banking should not be exaggerated. In other words, strengthening the application of bay' al' 'inah to avoid the element of a trick to practice riba seems to be a more practical solution than banning it totally.

\section{Standardizing the ta' wid rate}

Ta wid is one of the measures imposed by Islamic banks on defaulting customers. In general, according to the Qur'ān (3:130), charging borrowers due to late payment qualifies as riba (Ibn Kathīr, 2008). However, in the case of current Islamic banking operations, if this penalty is totally abolished, it may affect the banking practice altogether. In other words, any delay by customers will directly affect Islamic banks as the financier in terms of incurring additional expenditure such as the costs of issuing notices and letters, as well as legal fees (BNM, 2010). Moreover, the context of the verse is argued to be slightly different from the context of practicing late payment charges. Islamic banking institutions act as financial intermediaries between two sides, taking capital from one side, and offering financing to the other side (Briscoe and Fuller, 2007). When customers default or make late payments on their financings, it impacts the liabilities side of the bank as well (i.e. affecting deposit customers).

Realizing the maslahah behind this issue, many bodies allow the implementation of a late payment charge, but with different approaches. The IIFA, for example, has allowed Islamic banks to impose a penalty clause in a financial contract if any party causes harm to another, and the $t^{\prime}$ wid is imposed based on actual loss (IIFA, 2000). Nevertheless, AAOIFI in its Shari'ah standards mentioned that ta' wid should not be imposed, whether by mentioning this condition at the beginning of the contract or through court judgements. However, AAOIFI agrees that debtors should bear all expenses incurred by creditors resulting from the debt settlement process. It also allows the mention in the contract that if there is a delay in payment, debtors must donate a certain amount of money to charitable bodies, known as gharāmah (penalty) (AAOIFI, 2010). 
In the case of Malaysia, the SAC in its 4th meeting introduced a late payment charge for Islamic banks based on the concept of ta'wid. This charge must, however, fulfill three conditions: its amount cannot exceed the actual loss suffered by the Islamic bank, the compensation shall be determined by the central bank and the default or delay of payment must be applied only to customers who have not paid despite having the ability to do so (BNM, 2007). Later, gharāmah was introduced as another option for Islamic banks, as well as a combination of ta'wid and gharamah. The main difference between ta'wid and gharamah is that the former can be recognized as income while the latter must be channeled to charity. In addition, the rate of ta' wid must be imposed at one percent per annum, while gharämah can exceed 8 per cent per annum (BNM, 2015).

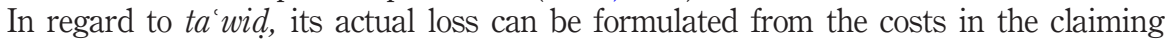
process of debt such as lawyers' fees, auction fees, storage fees and assessment fees, as well as communication costs (Md. Hashim et al., 2011). However, the different approach imposed by BNM in this case is to standardize the rate of $t a^{\prime}$ wid at one percent per annum (BNM, 2010). This could go against the original concept of $t a$ ' wid, which aims to cover the actual loss incurred due to the delay of payment. Moreover, one percent is similar to the late payment penalty imposed by many conventional banks in Malaysia, and this may cause the public to view both systems as having no appreciable difference.

Nevertheless, BNM's standardization of the ta' wid rate realizes greater maslahah. First, if Islamic banks were allowed to charge the actual loss based on their own judgement, it might lead to issues of transparency and exploitation of customers. Second, charging more than one percent and recognizing it as income would create a negative perception towards Islamic banks because it would be higher than the amount charged by their conventional counterparts. Third, ta wid is easier to apply without additional cost and effort in comparison with gharamah, which needs to be channeled to charitable organizations (Laldin, 2017). Finally, it is important to standardize the actual loss which usually is based on the cost of funds. Using an appropriate rate can avoid a disruption of the banking operation, including depositors' withdrawals, banks' earnings, and financing activities. All of them could affect both the reputation and image of the IFI (Md. Hashim et al., 2011).

To conclude the issue, it seems that maslahah of standardizing the rate of ta wid should be taken into consideration because it affects the viability of the Islamic banking industry. At the same time, it is important for Islamic banks to be careful in implementing ta wid. since late payment charges in Islam must be different from the practice of $r i b \bar{a}$. In this regard, even though the central bank has allowed ta'wid to be recognized as a bank's income, it would be better for Islamic banks to take a precaution in this matter. This includes recognizing only the actual loss and channeling the remaining money to charitable organizations.

\section{Stipulating ibrā' in financial agreements}

Technically speaking, $i b r \bar{a}$ is an action by lenders to withdraw their right to collect the debt from their borrowers (Mohamad and Trakic, 2013). Based on the majority of literature written by classical scholars, $i b r \bar{a}$ is considered a benevolent practice that is given at the sole discretion of the creditor without any consideration or counter-value (Abdul Khir, 2013). In modern Islamic banking, $i b r \bar{a}$ plays a significant role when Islamic banks implement floating rate pricing on their products. This results in two different prices: the maximum selling price, known as the ceiling rate, and the price calculated against the specific rate, known as the effective rate (Lahsasna, 2014). For example, in BBA financing, the selling price could be based on a profit rate of 10 per cent, but Islamic banks only require a 6 per 
cent effective rate based on the current financing because customers enjoy an $i b r \bar{a}$ ' of 4 per cent (BNM, 2019).

What made such practice of $i b r \bar{a}$ ' in Malaysia unique was when the central bank issued a special regulation that Islamic banks must incorporate a clause of $i b r \bar{a}$ and its calculation in their financing agreements. At the SAC's 101st meeting on 20 May 2010, this approach was introduced to further safeguard public interest and to ensure that customer protection is carried out consistently (BNM, 2013). Nevertheless, this resolution of the SAC appears contrary to the resolution of the IIFA, which says that $d a^{\prime}$ wa ta jil (reducing the amount for speeding up payment), is allowed as far as it is not agreed upon in advance (IIFA, 1992). In fact, the practice of $i b r \bar{a}$ in Islamic banking today is similar to the discussion of $d a^{\prime}$ wa $a^{\prime} j i l$ among classical scholars (Dusuki et al., 2010).

While this decision seems to be against the original concept of $i b r \bar{a}$ ' which should be at a bank's discretion, it protects the maslahah of customers, particularly in the case of early settlement, when a customer is liable to pay the entire selling price even though no deferment has been given to them to settle their debt (Abdul Khir, 2016). In this regard, to achieve the more important maslahah, in some cases, the specific mașlahah needs to be compromised. In this case, the maslahah of transparency and fairness between contracting parties must be seen as a priority instead of the original maslahah of $i b r \bar{a}$, which is to show benevolence. Also, this decision is argued to bring maslahah for the image of Islamic banks because, prior to this, many disputes between them and their customers were because of the unclear and unfair application of $i b r \bar{a}$ ' (Dusuki et al., 2010).

Nevertheless, it is also unfair to blame the original concept of $i b r \bar{a}$ ' when it is adopted only to justify the practice of floating rate, as well as to avoid the high price of Islamic banking products. Although Islamic banks have been established for more than half a century, their products are significantly influenced by interest rates. In addition, the predominant contracts being applied are debt-generating, which is a common factor they share with conventional contracts. Therefore, for the sake of long-term consequences, Islamic banking players must strengthen their effort to establish a better concept of financing for Islamic banks. For example, equity-based products such as mushärakah (partnership) contracts where $i b r \bar{a}$ is not implemented in their practice.

\section{Conclusion}

This paper has attempted to investigate several Islamic banking contracts and principles in Malaysia from the perspective of maslahah. While Malaysia is leading the Islamic banking industry in many aspects, BNM, through the SAC, has developed several resolutions which differ from those of some international bodies. Moreover, these resolutions are not being practised in some Muslim majority countries. These include allowing bay ' al-' $\bar{i}$ nah, standardizing the rate of $t a^{\prime}$ wid and stipulating the $i b r \bar{a}$ ' clause in financial agreements.

From the above discussion, it is found that BNM has attempted to consider the maslahah of both Islamic banks and their customers in its regulations. In the case of bay' al' ' $i n a h$, this contract helps to facilitate the bank's liquidity as well as helping to fulfill people's needs. As for $t a^{\prime}$ wid, standardizing its rate makes this penalty easier to impose, and also this approach can protect customers from exploitation. Meanwhile, requiring Islamic banks to stipulate an $i b r \bar{a}$ ' clause in their financial agreements not only protects customers in the case of early settlement, but it has also improved the image of Islamic banks because the previous practice of $i b r \bar{a}$ ' was claimed to be unfair. Thus, it can be concluded that the implementation of maslahah aims to sustain the viability of Islamic banks and ensure fairness and transparency between Islamic banks and their customers. 
Nevertheless, it is important for Islamic banking players to consider their current practices. In this regard, bay al-'inah should be replaced with another less controversial contract. As for ta' wid, it would be better for Islamic banks to recognize only the real cost from their one percent per annum charge and to channel the remaining money to charitable organizations. Meanwhile, in the case of $i b r \bar{a}$, Islamic banks can avoid this practice by offering equity-based products such as mushärakah instead of debt-based products that, it is argued, are not in line with the spirit of Islam.

\section{References}

AAOIFI (2010), Sharia Standards for Islamic Financial Institutions, Accounting and Auditing Organization for Islamic Financial Institutions, Manama.

Abdul Khir, M.F. (2013), "Ibra' and its application in Islamic finance”, ISRA Bloomberg Bulletin, pp. 1-4.

Abdul Khir, M.F. (2016), "Bilateral rebate (ibra' mutabadal) in Islamic banking operation: a critical appraisal", International Journal of Islamic and Middle Eastern Finance and Management, Vol. 9 No. 3, pp. 435-452.

Ahmad Bashar, M.L. (1997), "Price control in an Islamic economy", Journal of King Abdulaziz University-Islamic Economics, Vol. 9 No. 1, pp. 29-52.

Al-Dūrī, Q. (2011), Al-Ihtikīār wa Āthāruhu fì al-Fiqh al-Istāmī, Dār Kitāb-Nāshirūn, Beirut.

Al-Kaylānī, A. (2008), "Al-ta țbīq al-maqāșidī li al-ahkām al-shar 'iyyah", Al-Majallah al-Urduniyyah fī al-Dirāsah al-Istämiyyah, Vol. 4 No. 4, pp. 9-32.

Al-Khādimī, N. (2010), Al-Itihāà al-Maqāṣidī, Dār Ibn Hazm, Beirut.

Al-Qarad̄̄āī, Y. (2006), Dirāsāt fī Fiqh Maqāṣid al-Sharī ah bayna al-Maqāṣid al-Kulliyah wa al-Nuṣūs . al-Juz'iyyah, Dār al-Shurūq, Cairo.

Al-Raisūnī, A. (1995), Nazarīyyat al-Maqāṣid ‘inda al-Imām al-Shā țibī, International Institute of Islamic Thought, VT.

Al-Shāfi 'ī, M. (2001), Al-Umm, Dār al-Wafā’, Riyadh.

Al-Yūbī, M. (1998), Maqāṣid al-Sharī ah al-Istàmīyyah wa 'Atāqatuhā bi al-Adillah al-Shar ìyyah, Dār alHijrah, Riyadh.

Amer Hamzah, A.Z. and Vizcaino, B. (2014), "Malaysia tightens rules on divisive Islamic bai inah deals", Reuters, available at: www.reuters.com/article/us-islamic-finance-malaysia/malaysia-tightens-ruleson-divisive-islamic-bai-inah-deals-idUSBREA4K0FM20140521 (accessed 13 February 2019).

Askari, H., Iqbal, Z. and Mirakhor, A. (2009), New Issues in Islamic Finance and Economics: Progress and Challenges, John Wiley and Sons, Singapore.

Auda, J. (2007), Maqasid al-Shariah as Philosophy of Islamic Law: A Systems Approach, The International Institute of Islamic Thought, London.

BNM (2007), Resolutions of Shariah Advisory Council of Bank Negara Malaysia, Bank Negara Malaysia, Kuala Lumpur.

BNM (2010), Shariah Resolutions in Islamic Finance, 2nd ed., Bank Negara Malaysia, Kuala Lumpur.

BNM (2013), Guidelines on Ibra' (Rebate) for Sale-Based Financing, Bank Negara Malaysia, Kuala Lumpur.

BNM (2015), Guidelines on Late Payment Charges for Islamic Banking Institutions, Bank Negara Malaysia, Kuala Lumpur.

BNM (2019), Introduction of Islamic Variable Rate Mechanism, Bank Negara Malaysia, Kuala Lumpur, available at: http://iimm.bnm.gov.my/view.php?id=6\&dbIndex=0\&website_id=14\&ex=1369604548\& $\mathrm{md}=-\mathrm{Ax} \% \mathrm{~F} 5 \% 12 \% \mathrm{FA} \% 06 \% \mathrm{C} 49 * \% \mathrm{E} 1 \mathrm{~s} ! \mathrm{cf} \% \mathrm{C} 3$ (accessed 16 February 2019 ). 
Briscoe, S. and Fuller, J. (2007), Harriman's Financial Dictionary, Harriman House, Hampshire.

Dusuki, A.W. (2010), “Can Bursa Malaysia's Suq Al-Sila' (commodity murabahah house) resolve the controversy over tawarruq?", ISRA Research Paper No 10, International Shari'ah Research Academy for Islamic Finance, Kuala Lumpur.

Dusuki, A., Abdul Khir, M. and Muhammad, M. (2010), "Implementasi ibra' dalam produk berasaskan harga tangguh dalam sistem perbankan Islam: analisis dari perspektif operasi perbankan dan maqasid syariah”, ISRA Research Paper No 16, International Shariah Research Academy for Islamic Finance, Kuala Lumpur.

Ernst and Young (2016), World Islamic Banking Competitiveness Report 2016, available at: www.ey. com/Publication/vwLUAssets/ey-world-islamic-banking-competitiveness-report-2016/\%24FILE/ ey-world-islamic-banking-competitiveness-report-2016.pdf (accessed 16 February 2019).

Hassan, A. (2006), "Al-Tas 'īr fī al-fiqh al-Islami”, Majallah Jāmi ah Dimashq li al-'Ulum al-Iqtișadiyyah wa al-Qānūniyyah, Vol. 22 No. 1, pp. 455-474.

Ibn 'Āshūr, M.T. (2001), Maqūṣid al Sharī' ah al-Āstāmiyyah, Dār al-Nafā' is, Amman.

Ibn Kathīr, I. (2008), Tafsīr al-Qurān al-'Aẓ̌im, Mu' assasat al-Risālah al-Nāshirūn, Beirut.

Ibn Mājah, M. (2000), Sunan Ibn Mājah, Kitab Bhavan, New Delhi.

IIFA (1992), Qarār bi Sha'n al-Bay bi al-Taqsīṭ, International Islamic Fiqh Academy, available at: www.iifa-aifi.org/1849.html (accessed 5 April 2018).

IIFA (2000), Qarār bi Sha'n Mawdū' al-Shart al-Jază' $\bar{l}$, International Islamic Fiqh Academy, available at: www.iifa-aifi.org/2059.html (accessed 20 September 2017).

IIFA (2006), Qarār bi Sha'n al-Muwā' adah wa al-Muwātta'ah fì al' 'uqūd, International Islamic Fiqh Academy, available at: www.iifa-aifi.org/2214.html (accessed 20 September 2017).

Iqbal, Z. and Mirakhor, A. (2007), An Introduction to Islamic Finance, Theory and Practice, John Wiley and Sons, Singapore.

ISRA (2009), ISRA Compendium for Islamic Financial Terms (Arabic-English), International Shariah Research Academy for Islamic Finance, Kuala Lumpur.

ISRA (2011), Islamic Financial System: Principles and Operations, International Shariah Research Academy for Islamic Finance, Kuala Lumpur.

Lahsasna, A. (2014), Sharī ah Issues and Resolutions in Contemporary Islamic Banking and Finance, IBFIM, Kuala Lumpur.

Laldin, M.A. (2017), Personal communication, 13 April.

Laluddin, H. (2015), “Maslahah's role as an instrument for revival of ijtihad”, International Journal of Islamic Thought, Vol. 8 No. 12, pp. 27-34.

Malik, M. (2011), "Constructing the architectonics and formulating the articulation of Islamic governance: a discursive attempt in Islamic epistemology", doctoral thesis, Durham University, Durham.

Mansour, M. (2007), "Hukm bay'al- 'inah fī al-fiqh al-Islāmī al-muqārin wa ta ṭī̄ātuhu al-mu āṣirah", Majallah al-Sharī'ah wa al-Qānūn, Vol. 34 No. 2, pp. 225-248.

Md. Hashim, A., Hussain, L. and Hassan, S. (2011), "Cost of funds - is it a part of actual loss (ta'wid)?", ISRA International Journal of Islamic Finance, Vol. 3 No. 1, pp. 125-133.

Md. Hashim, A., Iqbal, I., Hussain, L., Muhammad, M., Abdul Khir, M.F. and Bouheraoua, S. (2015), "The parameters of hiyal in Islamic finance", ISRA Research Paper No 80, International Shariah Research Academy for Islamic Finance, Kuala Lumpur.

Mohamad, A.H. and Trakic, A. (2013), "Application and development of $i b r \bar{a}$ ' in Islamic banking in Malaysia", The Law Review, available at: www.tunabdulhamid.my/index.php/speech-paperslectures/item/505-application-and-development-of-ibra-in-islamic-banking-in-malaysia (accessed 16 February 2019). 
Mohammad, M.T., Abdullah, M.Y., Mohamad, M.A. and Zainal Abidin, U.Z. (2013), "The historical development of modern Islamic banking: a study in South-East Asia countries", African Journal of Business Management, Vol. 10 No. 20, pp. 1-14.

Shaharuddin, A. (2012), "The bay al-inah controversy in Malaysian Islamic banking", Arab Law Quarterly, Vol. 26 No. 4, pp. 499-511.

Tita, N. and Saim, K. (2012), "Application of bay' al-inah in Islamic banking and finance: from the viewpoint of siyasah shar iyyah", paper presented at the 3rd Annual Conference on RibaMultifaceted Global Crises of Riba: Resilience, Response and Reform, 26-27 November, Palace of the Golden Horses, Kuala Lumpur.

Van Greuning, H. and Iqbal, Z. (2008), Risk Analysis for Islamic Banks, World Bank, Washington, DC.

Yusof, S.M. (2017), "A study on bay al-murābahah in Islamic law and its application in Malaysian Islamic banks", $\mathrm{PhD}$ dissertation, University of Aberdeen, Scotland.

\section{About the author}

Muhammad Shahrul Ifwat Ishak, PhD, is a lecturer at Faculty of Economics and Management Sciences, Universiti Sultan Zainal Abidin (UnisZA), Malaysia. He obtained his PhD from the University of Aberdeen. His research interests focus on the application of maquasid al-Sharīiah (objectives of Islamic law) in Islamic banking. Muhammad Shahrul Ifwat Ishak can be contacted at: shahrulifwat@gmail.com

For instructions on how to order reprints of this article, please visit our website: www.emeraldgrouppublishing.com/licensing/reprints.htm Or contact us for further details: permissions@emeraldinsight.com 